\section{Dypdykk i randomiserte kliniske forsøk}

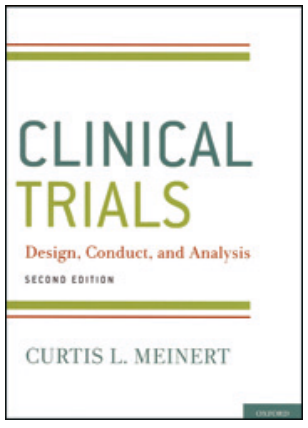

\section{Curtis L. Meinert \\ Clinical trials}

Design, conduct and analysis. 2. utg. $665 \mathrm{~s}$, tab, ill. Oxford: Oxford University Press, 2012 Pris GBP 80

ISBN 978-0-19-538788-9

Det finnes mange bøker om klinisk forskning generelt og randomiserte kliniske forsøk spesielt. Denne bør ikke være den første og kanskje heller ikke den andre man anskaffer seg. Intensjonen var å skape et referanseverk for designere og utøvere av randomiserte kliniske forsøk - og det er oppfylt. Metodeentusiaster som vil kunne mest mulig og gjøre alt korrekt, får et oppbyggende dypdykk.

Layouten er ikke altfor innbydende, med 665 sider med relativt liten fontstørrelse $\mathrm{i}$ to spalter, mange store tabeller med enda mindre fontstørrelse og få figurer. Den består av åtte deler: Introduction, Design principles and practices, Execution, Data analyses, Organization and management, Publication, Miscellaneous og Appendices, som igjen er delt i 52 kapitler. Appendices består av 12 vedlegg som utgjør 158 sider. Boken avsluttes med 574 referanser og et stikkordregister. Samlet gir det en god oversikt over temaet.

Dekningen av emner som jeg tror jeg behersker, er fullstendig og godt beskrevet. Selv om dette er temaer jeg er fortrolig med, bidro boken til økt innsikt. Lesing av kapitler som jeg har mindre kjennskap til, var lærerikt, men tyngre. Det er mange detaljer og uklart hva som er viktigst. Du får ingen rask oversikt ved å kaste et blikk på didaktiske figurer, oversiktlige tabeller og punktvise prioriterte lister. Boken må leses/studeres. Enkelte kapitler er bygd opp med spørsmål og svar som kontroll på at man har forstått forutgående kapitler.

Det henvises til regelverket i USA, U.S. Food and Drug Adminstration (FDA) og National Institutes of Health (NIH), uten at det byr på problemer. Noe er nyttig, mens mye raskt kan hoppes over. Vi må forholde oss til det norske regelverket for forskning.

Selv en så komplett bok har begrensninger. Hovedvekten er på randomiserte kliniske forsøk med parallelle grupper. Krysstudier (crossover/ multicrossover studies), enkeltpasientstudier (singlesubject studies), faktorielt- og sekvensielt design samt de mer spesielle, som Zelens design, «comprehensive cohort design» og Wennebergs design, er utelatt eller omtalt i begrenset omfang.

Stikkordregisteret er komplett og velfungerende og bidrar til at en omfattende og detaljert bok kan brukes som oppslagsverk. Fordi de færreste sammenlikninger kan gjøres med randomiserte kliniske forsøk, slik det påpekes i forordet, må man selvsagt også ha kjennskap til andre design.

Boken kan trygt anbefales for personer med stor interesse for randomiserte kliniske forsøk, med hovedvekt på parallelle grupper. Jeg vil bruke den med glede i mitt arbeid med forskning og undervisning.

\section{Per G. Farup}

Det medisinske fakultet

Norges teknisk-naturvitenskapelige universitet

\section{Globalisering og identitet i flertall}

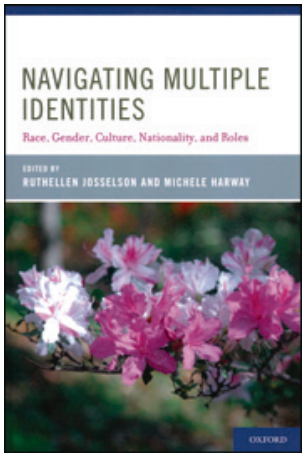

Ruthellen Josselson, Michele Harway, red. Navigating multiple identities

Race, gender, culture, nationality, and roles. 268 s. Oxford: Oxford University Press, 2012. Pris GBP 33

ISBN 978-0-19-973207-4

Dette er en bok om hvordan globaliseringen utfordrer personlig identitet. Her belyses erfaringer med å leve i lojalitetsspenn mellom kulturer og nasjonaliteter, og leseren får et innblikk i identitetsproblematikk knyttet til kjønn, rase og roller.

Boken er redigert av de to erfarne amerikanske forskerne Ruthellen Josselson og Michele Harway. De er begge psykologer og har skrevet et fyldig innledningskapittel der de begrunner behovet for å fornye identitetsforskningen ved hjelp av kvalitative metoder. Totalt er det 13 kapitler, de fleste skrevet av psykologer med tilhørighet i amerikanske forskningsmiljøer.

Hvordan bygges identiteten hos en velutdannet kvinne som forvalter et vestlig verdisett samtidig som hun er en pliktoppfyllende datter av en pakistansk far i en tradisjonell muslimsk familie? Hvordan navigerer hun mellom identiteter og selvpresentasjoner? Hvordan kan skiftende sosiale og kulturelle referanserammer inkluderes til en ny helhet? Dette er noe av det som belyses. De fleste kapitlene sirkler rundt spørsmål som: «Hvem er jeg?» og «Hvem kan jeg bli i en verden hvor kontakten over kulturgrenser øker i omfang og intensitet?»

Kapitlene spenner fra en analyse av de emosjonelle og kognitive prosessene som president Obama beskriver i memoaren Dreams from My Father (1), til gutter som bruker sin maskulinitet for å hele såret identitet. Flere kapitler har et individfokus, mens andre tar for seg krysskulturelle befolkningsgrupper. Gjennom dyptpløyende analyser (særlig narrative) av identitetsprosesser viser forfatterne frem polariseringer, flertydighet, muligheter og sårbarhet $\mathrm{i}$ danningen av identitet.

Verdien ligger først og fremst $i$ de grundige beskrivelsene av hvordan personer og grupper som lever $i$ et kulturelt krysspress forstår seg selv og sin egen identitet. Spennet i det som beskrives er vel stort, fra Obamas identitetsforvaltning, via kjønnsidentitet i feministiske pressgrupper, til psykologiske erfaringer med å være barn av colombianske immigranter i USA. Rekken av meget gode narrative analyser er en klar styrke. Det viser gevinstene ved å bruke kvalitative metoder når kategorier som amerikansk - «hispanic» ikke lenger er gjensidig ekskluderende. Dessverre mangler et avslutningskapittel om hva de ulike analysene samlet sett har gitt av innsikt om det å navigere mellom multiple identiteter i en globalisert verden.

\section{Kristin Heggen}

Det medisinske fakultet

Universitetet i Oslo

\section{Litteratur}

1. Obama B. Dreams from my father: A story of race and inheritance. New York, NY: Random House, 2004. 